\title{
Trajectories of First-Time Mothers' Depressive Symptoms During Six Years Postpartum and Behavioral Problems of Their First Child at Age 6 Years
}

\author{
Yeon Ha Kim \\ Associate Professor, Department of Child \& Family Studies, Kyung Hee University, Seoul, Korea \\ 어머니의 첫 출산 후 6년간 우울 궤적과 만 6세 첫 자녀의 문제행동 \\ 김연하 \\ 경희대학교 아동가족학과 부교수
}

Objectives: This study aimed to identify the trajectories of depressive symptoms of 965 first-time mothers during six years postpartum, and to explore the differences in the behavioral problems of their first child at age 6 years according to the depressive symptom trajectories.

Methods: Maternal depressive symptom trajectories were identified using latent growth class modeling. Differences in the behavioral problems of children according to maternal depressive symptom trajectory were analyzed with analysis of covariance.

Results: There were five trajectories of depressive symptoms (no symptoms, $25.9 \%$; low symptoms, 43.2\%; decreasing symptoms, $6.6 \%$; moderate symptoms, $18.6 \%$; severe symptoms, $5.9 \%$ ) among Korean first-time mothers. The problematic behaviors of children with mothers in the moderate and severe symptoms groups were significantly higher than those of children with mothers in the no symptoms group.

Conclusions: Regarding maternal depression, identifying at-risk mothers after first delivery and supporting them are critical. For children exposed to severe and chronic maternal depressive symptoms during early childhood, special attention on their socio-emotional development is needed.

Keywords: first delivery, trajectory of depressive symptoms, behavioral problem, first child

\section{Introduction}

우울은 기분 저하, 집중, 기억, 의욕, 관심 같은 전반적인 정신 기능 저하와 수면, 식욕 등의 신체기능 저하도 동반하는 정신 건강 문제이다. 만약 부모, 특히 주 양육자인 어머니가 우울하 다면 자녀의 양육에 부정적 영향을 준다. 특히 생애 초기에는 건강한 애착형성을 위해 주 양육자가 아동의 신호에 계속해

Corresponding Author: Yeon Ha Kim, Associate Professor, Department of Child \& Family Studies, Kyung Hee University, 26, Kyunghee-daero, Dongdaemun-gu, Seoul, Korea

E-mail: yeonhakim@khu.ac.kr
서 관심을 집중하고, 이에 즉각적이고 민감하게 반응해야 하 는데, 만약 주 양육자인 어머니가 우울하면 정신과 신체기능 의 저하로 인해 아동이 보내는 신호를 무시하거나 잘못 해석 하여 반응하기 쉽다. 우울한 어머니와 일반 어머니의 영아-어 머니 상호작용을 비교해 보면, 우울한 어머니들은 영아를 먹 이고 어르고 만져주는 행위를 덜 하며, 영아가 울 때 돌보는 행 동을 덜 보이며, 영아가 아주 큰 소리로 울 때만 주로 반응하는

(C) The Korean Association of Child Studies

This is an Open Access article distributed under the terms of the Creative Commons Attribution Non-Commercial License (http:// creativecommons.org/licenses/by-nc/4.0) which permits unrestricted noncommercial use, distribution, and reproduction in any medium, provided the original work is properly cited. 
경향이 있다(Esposito, Manian, Truzzi, \& Bornstein, 2017; Lee, Lee, Chung, \& Shin, 2011). 이렇게 주 양육자의 우울로 인해 손상된 상호작용 방식에 장기간 노출된 아동은 극심한 스트레 스를 경험하게 되고 이로 인해 발달적 손상을 입게 된다(Lebel, 2016). 아동이 이러한 발달적 손상을 입게 되면 사회, 정서, 인지, 신체 발달에 장기적인 부정적 결과가 나타난다(Betts, Williams, Najman, \& Alati, 2015).

우울은 지속기간과 심각성의 개인차가 큰 질환이다. 우 울은 단순한 우울감에서부터 심각한 주요 우울증(major depressive disorder)까지 그 증세가 다양하며, 어떤 사람은 며칠 만에 우울감에서 벗어나기도 하지만 어떤 사람은 수년간 우울 증에서 헤어 나오지 못하기도 한다. 따라서 우울을 연구하기 위해서는 어느 한 시점에서 그 사람의 우울증상을 파악하기 보다는 장기적 관점에서 그 사람의 우울증상이 얼마나 심각하 고 지속적인가를 파악하는 것이 필요하다. 최근 우울증상의 종단적 발달궤적을 유형화 하는 연구가 활발하게 이루어지고 있다. 예를 들면, Lim과 Choi (2016)는 한국 아동청소년 패널 조사 자료를 활용하여 남녀 청소년의 우울 증상을 분석하였는 데, 남자 청소년의 우울 발달궤적을 저수준 감소집단과 중간 수준 유지집단, 여자 청소년의 우울 발달궤적을 저수준 유지 집단, 중간수준 유지집단, 고수준 유지집단으로 분류한 바 있 다. Hoe (2014)는 한국복지패널을 활용하여 성인 남녀 8,900 명의 우울 증상을 분석하였는데, 우리나라 성인의 우울증상 변화 궤적에는 5개의 하위 집단이 존재한다고 보고하였다. Campbell, Matestic, von Stauffenberg, Mohan과 Kirchner (2007) 는 미국 어머니들의 출산 후 7년간 우울증상을 여섯 개의 궤적 으로 분류한 바 있다.

어머니 우울도 심각성과 지속성에서 개인차가 매우 크다. 우선 어머니의 우울이 얼마나 만성적(chronicity)인가에 따라 어머니-자녀 상호작용의 손상정도와 아동의 발달 양상이 다 르게 나타날 수 있다. 어머니 우울의 만성성에 따른 상호작용 방식과 아동 발달 양상을 살펴본 한 연구(Campbell, Cohn, \& Meyers, 1995)에 따르면, 2개월 정도 우울이 지속된 어머니의 상호작용방식은 일반 어머니들과 차이가 없지만, 6 개월 이상 우울이 지속된 어머니의 상호작용은 일반 어머니들에 비해 현 저하게 덜 긍정적인 것으로 나타났다. 또한 이렇게 오랫동안 우울한 어머니의 영아들의 얼굴 표정은 일반 어머니들의 영아 들에 비해 덜 긍정적이었다.

어머니 우울이 얼마나 심각한가(severity)도 중요한 변수이 다. 어머니의 우울과 만 5 세 아동의 발달과의 종단적 관계를 살펴본 한 연구에 따르면(Hammen \& Brennan, 2003), 어머니
의 우울이 심각할수록 만 5 세 자녀의 어휘력이 낮고 문제행동 수준이 높았다. 어머니 우울의 심각성과 만성성의 상호작용 효과도 문제행동 수준에 유의하게 작용하였다.

어머니 우울의 만성성과 심각성 이외에도, 아동이 언제 우 울한 어머니에게 노출되었는가(timing)도 '어머니 우울-왜곡 된 상호작용 방식-아동의 발달적 손상’ 간의 관계에서 변수로 작용 될 수 있다. 두뇌의 가소성이 높고, 사회 인지 정서발달의 결정적 시기인 생애 초기에 어머니의 우울에 노출된 것과 두 뇌발달이 어느 정도 완성된 아동기 이후에 어머니의 우울에 노출된 것은 발달적으로 다른 의미를 지닌다. 우울한 어머니 의 자녀들과 그렇지 않은 어머니들의 7세 자녀의 스트레스 호 르몬 수치를 비교한 연구결과에 따르면, 우울한 어머니를 둔 아동들의 스트레스 호르몬 수치가 훨씬 높으며, 특히 생애 초 기 즉 만 2세 이전에 어머니의 우울에 노출되었는가 여부가 7 세 아동의 스트레스 호르몬 수치를 예측하는 중요한 요인이었 다(Ashman, Dawson, Panagiotides, Yamada, \& Wilkinson, 2002), 이러한 연구결과들을 종합하면, 어머니의 우울 증상이 심각할 수록, 오랜 시간 지속될수록, 어머니의 우울에 노출된 자녀가 어릴수록, 자녀의 발달에 부정적인 영향을 준다고 볼 수 있다.

따라서 어머니의 우울과 아동의 발달간의 관계를 규명하기 위해서는 한 시점에서 어머니 우울증상과 자녀의 발달과의 관 계를 횡적으로 파악하는 것 보다 종단적 자료를 사용하여 어 머니의 우울발달궤적을 유형화 하고 이를 아동의 연령과 부합 시켜 살펴보는 것이 필요하다. 이를 통해 어머니 우울의 만성 성, 지속성 및 아동의 노출 연령에 따라 발달적 손상이 어떤 양 상으로 나타나는 가에 대한 풍부한 정보를 얻을 수 있다.

최근 우리나라에서도 어머니의 우울과 자녀의 발달을 살펴 본 연구가 많이 이루지고 있다. 그 중에서도 특히 어머니의 우 울이 자녀의 내재적 외현적 문제행동과 어떠한 관련이 있는가 가 집중적으로 연구 되었다. Joh와 Chang (2018)은 어머니 우 울의 만성도와 아동의 외현적 내재적 문제행동 및 온정적 양 육태도와의 관련성을 조사하였는데, 어머니의 우울이 만성적 일수록 온정적인 양육태도가 낮아지고, 문제행동 수준이 높아 짐을 보고하였다. C.-K. Kim과 Cho (2017)도 비슷한 연구결과 를 보고하였다. 어머니의 우울과 아동의 문제행동간의 종단적 관계를 분석한 결과 어머니의 우울은 온정적 양육행동을 통 해 유아의 문제행동에 영향을 주었다. S.-H. Kim (2016)은 어 머니의 우울, 아동의 불안, 내재화 문제행동간의 관계를 종단 적으로 분석하였는데, 유아가 0 세 때 어머니 우울의 수준이 높 으면, 유아의 부정적 정서성이 점차로 증가하고, 이는 다시 유 아의 4 세 때 높은 내재화 행동문제 수준으로 이어졌다. 이러한 
연구들은 우리나라 어머니들의 우울과 아동의 사회성 발달간 의 관계에 대한 실증적인 정보를 제공하고 있어 그 가치가 매 우 높다. 하지만 어머니 우울의 종단적 발달궤적을 유형화 하 여 어머니의 우울의 심각도와 만성성 및 우울에 노출된 아동 의 연령이 아동발달에 어떤 역할을 하는가를 종합적으로 살펴 본 국내 연구는 아직 부족한 실정이다.

본 연구에서는 어머니들의 출산 후 6 년간 우울증상에 대한 발달 궤적을 잠재계층 성장모형(latent class growth modeling)을 통해 종단적 분류하고, 어머니의 우울 발달궤적에 따른 아동 의 내재적 외현적 문제행동의 차이를 살펴보고자 한다. 잠재 계층 성장모형은 반복 측정된 개인 내 변인들을 분석하여, 유 사한 패턴을 가진 개인들끼리 분류하는 분석(A. Kim \& Kim, 2018; Muthén \& Muthén, 2000)으로 우울 발달궤적을 분석하 는데 널리 사용되고 있다. 본 연구에서도 첫 출산 후 6년간 우 울 증상(심각도와 만성성)의 유사성에 따라 어머니들이 몇 개 의 독립적인 집단으로 유형화될 것으로 예측된다. 또한 아동 의 문제행동도 생후 6년 동안 어머니의 우울 궤적이 언제, 얼 마동안, 어느 정도 심각한 수준이었는가에 따라 차이가 나타 날 것으로 예측된다. 만 6 세는 유아기에서 아동기로 전이하는 시기이다. 유아기에는 발달적 문제행동과 사회 정서적 부적 응으로 인한 문제행동을 구분하는 것이 쉽지 않지만 6 세 정도 가 되면 발달적 문제행동이 어느 정도 사라진다(Yoo, 2013). 따 라서 만 6 세의 문제행동 수준은 영유아기 사회.정서 발달을 총 체적이면서 비교적 정확하게 반영하는 발달적 지표라고 볼 수 있다. 특히 만 6세 아동은 초등학교 입학을 앞두고 있고, 이 시 기의 아동의 문제행동 수준은 초등학교 적응과 밀접하게 관련 이 있는 만큼 그 중요성이 더 크다고 볼 수 있다. 이에 본 연구 는 아동의 6세 때 문제행동 수준을 종속변수로 설정하였다.

한편, 기존의 어머니 우울-자녀 발달에 관한 연구는 그 대 상을 선정할 때 자녀의 출생순위를 고려하지 않아서 그 결과 에 어머니가 손위 자녀 양육으로부터 얻은 경험과 지식이 통 제되지 않은 채 반영되어 있는 경우가 많았다. 이에 본 연구 는 연구 대상을 첫 출산한 어머니와 첫 자녀로 한정하였다. 이 를 통하여 어머니 우울-자녀의 발달 관계에서 어머니가 기존 의 출산과 양육으로부터 얻은 경험과 지식의 영향력을 배제하 고자 한다. 첫 출산으로 인한 급격한 변화에 적응하면서 처음 으로 자녀를 양육하는 것은 어머니의 인생에 단 한번 찾아오 는 경험이다. 어떤 어머니는 이 변화에 잘 적응하기도 하고 어 떤 어머니는 심각한 스트레스와 불안을 경험하기도 한다. 첫 출산한 어머니와 그들의 첫 자녀를 대상으로 어머니의 우울과 아동발달의 종단적 관련성을 살펴보는 것은 부모의 정신건강
과 아동발달에 관한 엄정하고 풍부한 자료를 구축하는데 반드 시 필요하다.

본 연구에서 탐색하고자하는 주요 연구문제는 다음과 같 다.

\section{연구문제 1}

첫 출산한 어머니들의 산후 6 년간 우울 발달 궤적은 어떻게 분류되는가?

\section{연구문제 2}

어머니들의 우울 발달궤적에 따라 첫 자녀의 만 6 세 때 문제 행동 수준은 차이가 있는가?

\section{Methods}

\section{연구대상}

본 연구의 대상은 육아정책 연구소에서 실시한 한국아동패널 (Pannel Study of Korea Children [PSKC])에 참여한 2078 가족 중 2008년도에 출산한 자녀가 첫 자녀인 총 965 명의 어머니와 그 첫 자녀이다(Table 1). 한국아동패널은 층화다단계 표본추 출법을 활용한 전국 규모(제주도 제외)의 종단연구이다. 본 연 구는 1차년도(2008년)부터 7차년도(2014년)자료를 활용하였 으며, 7차년도 당시 표본 유지율은 $75.3 \%$ 이었다.

첫 자녀 출산 당시 어머니의 평균연령은 30.11 세이며, 아버 지의 평균연령은 약 32.55 세이었다. 아버지와 어머니의 학력 을 대졸이하와 고졸이하로 나누어 보았을 때 어머니의 $72.5 \%$, 아버지의 $71.6 \%$ 가 대졸이상이었다. 출산 당시 취업중인 어머 니는 $32.5 \%$ 이었다. 아동의 성별은 남아가 $53.3 \%$ 이었으며, 아 동 출생 당시 가족의 월평균 수입은 311.700 만원이었다.

\section{연구도구}

\section{어머니의 우울}

한국아동패널은 한국어로 번안된 자기보고식 Kessler의 우울 척도(Kessler et al., 2003)를 사용하여 어머니의 우울증상을 출 산당시, 출산 1 개월 후, 출산 4 개월 후, 출산 1 년 이후부터 매 해 한번 씩 측정하고 있다. 본 연구에서는 첫출산 당시(0개월, 병원조사) 1 개월 후( 1 개월, 전화조사), 4 개월 후(이후 어머니 
Table 1

Characteristics of Participants

$\begin{array}{lll}\text { Characteristics } & M(S D) & \%\end{array}$

Age at first childbirth (year)

Mother

$30.11(3.641)$

Father

32.55 (3.997)

Education (college + )

Mother

Father

71.6

Employment status of mother

32.5

Sex of first child (boys)

53.3

Family income in 2008 (monthly, Korean won)

$311.700(140.9120)$

Note. $\quad N=965$.

질문지 사용), 출산 후 1 년(12개월)에서 출산 후 6년(72개월)까 지 총 9번의 우울증상 점수를 사용하여 우울증상 궤적을 탐색 하였다.

Kessler의 척도는 “불안하셨습니까?”, "무기력하셨습니까?”, "안절부절 못하셨습니까?”, "매사에 힘이 드셨습니까?”, ”너무 슬퍼서 뭘 해도 기운이 나지 않으셨습니까?”, ”자기 자신이 가 치 없는 존재라고 느끼셨습니까?”의 총 6문항으로 이루어 졌 으며, 전혀 안 느낌(1점)에서 항상 느낌(5점)의 5점 척도로 평 정한다. 6 문항 총점의 점수가 높을수록 우울 정도가 높음을 의 미한다. 총 30 점 만점이고 13 점 이하는 정상, 14 점 이상이면 경도(moderate), 19점 이상이면 중도(severe) 우울증상을 의미 한다. Kessler 문항의 신뢰도(Cronbach's $\alpha$ )는 9차시 모두.80 이 상으로 양호하였다(예: 1차시는 .82: 9차시는 .91).

\section{자녀의 문제행동}

첫 자녀 6세 때의 문제행동 수준은 유아행동평가척도(Child Behavior Check List 1.5-5 [CBCL 1.5-5])(Y. A. Kim, Lee, Moon, $\mathrm{Kim}, \& \mathrm{Oh}, 2009)$ 를 사용하여 측정하였다. CBCL 1.5-5 는 총 100 문항으로, 7 개의 증후군 척도(정서적 반응성, 불안/우울, 신체증상, 위축, 주의집중문제, 공격행동, 수면문제)와 1 개의 기타 척도로 구성되어 있다. 보호자에 의해 전혀 해당되지 않 는다(0점), 가끔 그렇거나 그런 편이다(1점), 자주 그런 일이 있거나 많이 그렇다(2점)의 범위에서 응답하도록 구성되었다.

내재화된 문제는 정서적 반응성, 불안/우울, 신체증상, 위축 의 증후군 척도로 측정하며 점수가 높을수록 지나치게 내재화 되고 통제된 행동을 보임을 의미한다. 외현화된 문제는 주의집
중 문제와 공격행동 증후군 척도로 측정하며 점수가 높을수록 공격성과 주의집중이 외부적으로 통제가 안 되는 행동 양상을 보임을 의미한다. 문제행동 총점은 내재화 및 외현화 문제에 수면문제 증후군 척도와 기타 척도를 합하여 산출한다.

한국아동패널은 주양육자의 응답을 토대로 아동들의 만 4 세, 5세, 6세 때 CBCL 1.5-5의 원점수, T점수, 백분위 점수를 제공하고 있는데, 본 연구에서는 만 6세 때의 내재화된 문제, 외현화 문제, 문제행동 총점의 원점수를 활용하였다.

\section{자료분석}

첫 출산 후 6년간 어머니의 우울증상 궤적은 Mplus (Muthén \& Muthén, 1998-2002)를 이용한 잠재계층 성장모형(latent class growth modeling)을 사용하여 분석하였다. 우울증상 궤적에 따 라 첫 자녀의 만 6 세 때 문제행동 수준에 차이가 있는지를 살 펴보기 위해서는 SPSS 21.0 (IBM Co., Armonk, NY)을 이용하 여 공분산분석(analysis of covariance)을 실시하였다. 통제된 공 변량은 아동의 성별, 부모의 교육수준, 가정의 월수입, 어머니 의 취업여부, 어머니가 아동의 문제행동을 평가할 당시(아동 만 6세, 즉, 출산 후 72 개월)의 우울증상이다.

본 연구의 종속변인인 아동의 문제행동은 어머니에 의해 평가되었는데, 우울한 어머니는 아동의 문제행동을 왜곡하 거나 과도하게 해석하는 경향이 있다(Fergusson, Lynskey, \& Horwood, 1993). 따라서 아동의 문제행동을 평가할 당시의 어 머니의 우울 증상을 통제하여 연구결과의 객관성을 확보하고 자 하였다. 


\section{Results}

\section{첫 출산 후 어머니의 우울 발달 궤적}

기존의 성인을 대상으로 한 우울 궤적 연구들이 모집단에 3-6 개 정도의 잠재 궤적이 존재함을 보고하였으므로(Campbell et al., 2007; Hoe, 2014; Lim \& Choi, 2016), 본 연구에서도 첫 출 산한 어머니들의 우울증상을 3-6개의 1차형(linear) 혹은 2차 형(quadratic) 궤적으로 분석해보고, 그 결과를 비교하여 최선 의 모델을 찾고자 하였다. 판단을 위한 지표로는 Entropy (1에 가까울수록), Bayesian Information Criteria (BIC) (작을수록), probabilities of group membership (최소한 .70이상), Lo-MendellRubin Likelihood ratio Chi-square test (LMR-LRT) 유의 수준(.05 수준에서 유의)이 사용되었다(Hoe, 2014; Jung \& Wickrama, 2008) (Table 2). 분류된 궤적이 얼마나 상호 독립적이며 설명 력이 있는가를 시각적으로 판단하기 위해 각 분석에서 도출된 추정평균과 집단평균의 그래프도 활용되었다.

모형들을 비교해 보면, 3 개의 궤적 모형은 Entropy는 우수 한 편이었으나 BIC가 크고 그래프 확인결과 6년간의 우울증 상을 고 중 저 집단으로 지나치게 단순하게 궤적화하여 배제 되었다. Entropy가 가장 1 에 가까운 모형은 4 개의 궤적으로 이루어진 1차형 모형이었으나 BIC가 큰 편이고 LMR-LRT가 유의하지 않았다. 그 다음으로 1에 가까운 Entropy를 가진 모 형은 6 개의 궤적으로 이루어진 1차형 모델이었다. 이 모형은 LMR-LRT도 유의하고 BIC도 제일 작았지만 그래프 확인 결 과 궤적들 간의 중첩이 심한 것으로 나타났다. 최종적으로 5 개 의 궤적으로 이루어진 2 차 모형을 선정하였다. 이 모형은 두 번째로 작은 BIC, 중간 수준의 Entropy 유의한 수준의 LMRLRT를 보여 주었으며, 그래프 확인 결과 궤적들이 모두 우수
한 독립성을 가지고 있었다. 즉, 우리나라 어머니들의 첫 출산 후 6년간의 우울증상 궤적은 다섯 개의 2차형 궤적으로 설명 하는 것이 가장 타당하다고 판단되었다.

첫 출산 후 6년간 어머니들의 우울증상은 Figure 1 과 Table 3 에 제시되었다. 모든 궤적에서 우울증상의 집단평균이 출산 1 개월 무렵에 일시적으로 감소하는 경향이 공통적으로 나타났 으나, 각 우울 궤적은 그 심각성, 지속성에 있어서 서로 뚜렷한 차이가 있었다. 따라서 어머니들의 우울 궤적은 '증상 없음'(no symptoms, 25.9\%), '낮은 증상'(low symptoms, $43.2 \%)$, '증상 완화'(decreasing symptoms, 6.6\%), '경도 우울증상'(moderate symptoms, $18.6 \%$ ), '중도 우울증상'(severe symptoms, 5.9\%)으 로 명명되었다.

증상 없음과 낮은 증상집단의 우울증상은 우려할 만한 수 준은 아니었다. 증상 완화집단의 어머니들은 첫 출산 직후 약 2-3년간은 상당한 수준의 우울 증상을 보였으나 점차 완화되 어 첫 자녀가 만 6 세 무렵에는 낮은 증상의 어머니들과 유사한 수준이 되었다. 반면 경도 우울증상 집단은 경도에 해당하는 14 점에 근접하거나 상회하는 우울증상을 6년간 유지하고 있 었다. 중도 우울증상 집단도 중도에 해당하는 18 점에 근접하 거나 이를 횔씬 상회하는 증상이 6년간 유지되었다.

\section{어머니 우울궤적에 따른 만 6 세 아동의 문제 행동}

어머니의 우울 궤적에 따른 아동의 문제행동 수준을 기술적으 로 살펴보면 증상 없음 집단의 추정평균이 가장 낮았다. 이후 낮은 증상, 증상 완화, 경도 우울증상, 중도 우울증상 집단의 순서로 첫 자녀의 문제행동 수준이 높아졌다.

공분산 분석 결과(Table 4), 어머니 우울증상 궤적의 주효과

Table 2

Statistical Indices of Growth Mixture Modeling for Three to Six Trajectories of Maternal Depressive Symptoms

\begin{tabular}{|c|c|c|c|c|c|}
\hline Number of & f trajectories & Entropy & $\mathrm{BIC}$ & $\begin{array}{c}\text { Average posterior } \\
\text { probabilities of } \\
\text { group membership range }\end{array}$ & $\begin{array}{c}\text { LMR-LRT } \\
p \text { value }\end{array}$ \\
\hline \multirow[t]{2}{*}{3} & Linear & .774 & 39490.953 & $.889 \sim .914$ & .0000 \\
\hline & Quadratic & .777 & 39413.260 & $.884 \sim .924$ & .0000 \\
\hline \multirow[t]{2}{*}{4} & Linear & .819 & 39502.101 & $.861 \sim .916$ & .3900 \\
\hline & Quadratic & .705 & 39305.583 & $.784 \sim .915$ & .0022 \\
\hline \multirow[t]{2}{*}{5} & Linear & .722 & 39288.777 & $.744 \sim .902$ & .0792 \\
\hline & Quadratic & .725 & 39219.236 & $.751 \sim .929$ & .0294 \\
\hline \multirow[t]{2}{*}{6} & Linear & .749 & 39300.492 & $.729 \sim .996$ & .0145 \\
\hline & Quadratic & .701 & 39217.655 & $.664 \sim .913$ & .6196 \\
\hline
\end{tabular}




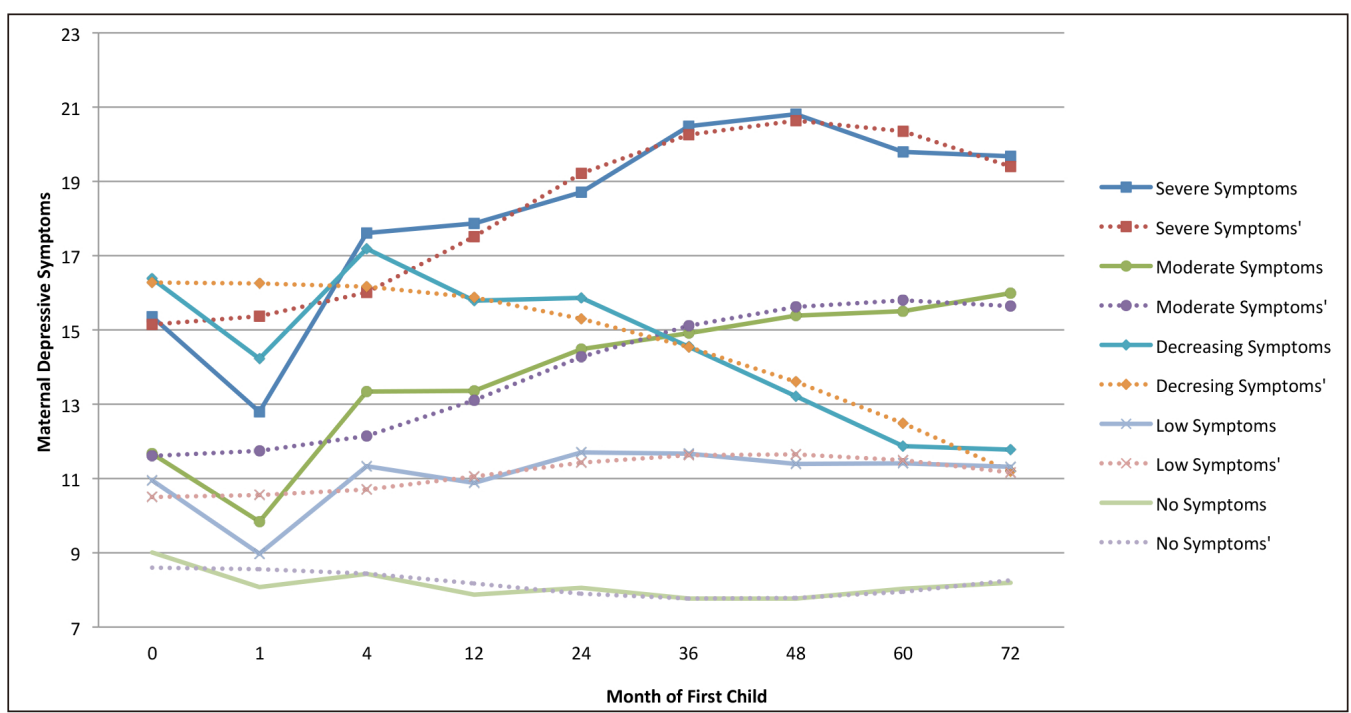

Figure 1. Trajectories of maternal depression during six years after first childbirth: Sample and estimated(') means.

Table 3

Sample (Estimated) Means of Maternal Depression for Six Years After First Childbirth

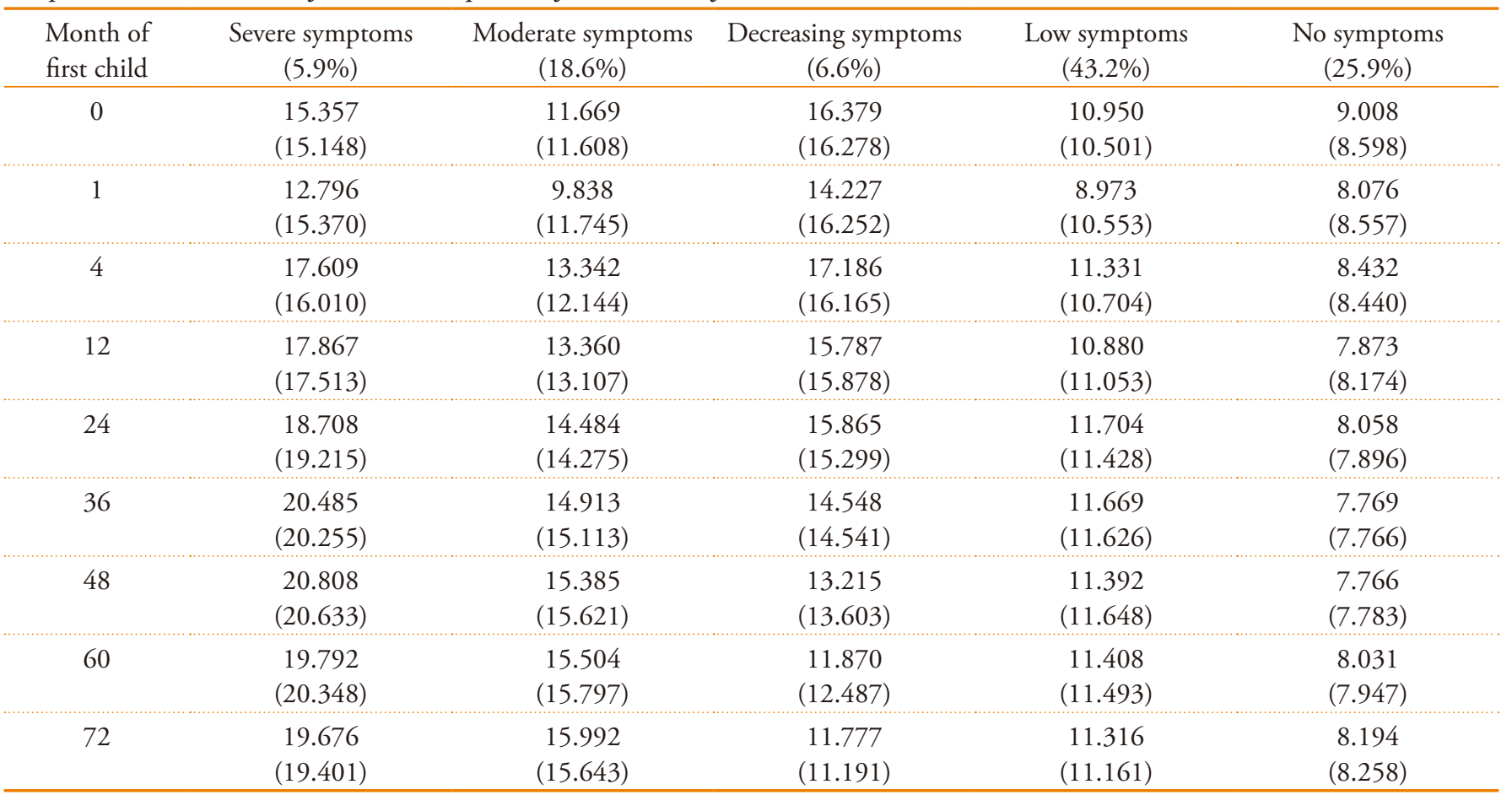

는 내재화 문제행동 수준 $\left(F(4,622)=3.69, p=.006, \eta_{\mathrm{p} 2}=.023\right)$, 외현화 문제행동 수준 $\left(F(4,622)=5.12, p=.000, \eta_{\mathrm{p} 2}=.032\right)$, 문 제행동 총점 $\left(F(4,622)=4.55, p=.001, \eta_{\mathrm{p} 2}=.028\right)$ 모두 통계적 으로 유의하였다. 즉, 모든 통제변인의 영향력을 제거하더라 도, 어머니의 우울증상 궤적에 따른 아동의 문제행동 수준은 유의한 차이가 있었다.
증상 없음 집단의 첫 자녀 문제행동 수준을 준거로 하여 평 균차를 비교하였을 때(Table 5), 경도 우울증상 집단과 중도 우 울증상 집단 어머니들의 첫 자녀의 문제행동 총점, 내재화 문 제행동, 외현화 문제행도 수준이 유의하게 높았다(Figure 2). 즉, 첫 출산한 어머니가 경도 또는 중도 이상의 우울 증상을 장 시간 호소한 경우, 첫 출산 후 우울증상이 없는 어머니에 비하 
Table 4

Effects of Maternal Depression Trajectories on Behavioral Problems: Analysis of Covariance

\begin{tabular}{|c|c|c|c|c|c|c|c|}
\hline \multirow[b]{2}{*}{ Source } & \multirow[b]{2}{*}{$d f$} & \multicolumn{2}{|c|}{ Internal problems } & \multicolumn{2}{|c|}{ External problems } & \multicolumn{2}{|c|}{ Total } \\
\hline & & F & $\eta_{\mathrm{p} 2}$ & F & $\eta_{\mathrm{p} 2}$ & $F$ & $\eta_{\mathrm{p} 2}$ \\
\hline Maternal education & 1 & .040 & .000 & .879 & .001 & .009 & .000 \\
\hline Paternal education & 1 & .201 & .000 & .439 & .001 & .039 & .000 \\
\hline Family income & 1 & .321 & .000 & 1.131 & .001 & .555 & .001 \\
\hline Child gender & 1 & .142 & .000 & $7.803^{* *}$ & .012 & .896 & .001 \\
\hline Employed mothers & 1 & .328 & .001 & .293 & 000 & .571 & 001 \\
\hline Maternal depression at 72 month & 1 & $9.487^{* *}$ & .015 & 2.837 & .005 & 6.409 & .010 \\
\hline Trajectories of maternal depression & 5 & $3.694^{* *}$ & .023 & $5.120^{* * *}$ & .032 & $4.545^{* *}$ & .028 \\
\hline Error & 623 & & & & & & \\
\hline & & \multicolumn{2}{|c|}{$R^{2}=.124$} & \multicolumn{2}{|c|}{$R^{2}=.123$} & \multicolumn{2}{|c|}{$R^{2}=.124$} \\
\hline
\end{tabular}

Note. $N=633$.

${ }^{* *} p<.01 .{ }^{* * *} p<.001$.

Table 5

Behavioral Problems of Children at age 6 Years Classified by Maternal Depression Trajectory: Adjusted for Covariates: Estimated Means (Standard Error)

\begin{tabular}{lrrrrc}
\hline \multicolumn{1}{c}{ Behavior problems } & No symptoms & Low symptoms & Decreasing symptoms & Moderate symptoms & Severe symptoms \\
\hline Internal & $6.14(.58)$ & $7.54(.38)$ & $8.44(1.01)$ & $9.32(.73)^{*}$ & $11.50(1.23)^{*}$ \\
External & $5.08(.48)$ & $6.15(.32)$ & $6.76(.84)$ & $8.22(.61)^{* *}$ & $10.34(1.03)^{* * *}$ \\
Total & $18.51(1.46)$ & $21.95(.96)$ & $24.95(2.54)$ & $27.40(1.84)^{* *}$ & $33.27(3.11)^{* *}$ \\
\hline
\end{tabular}

Note. Covariates are maternal education (2008), paternal education (2008), family income (2008), child's sex (2008), employment status of mothers (2008) and maternal depressive symptoms (2014).

* indicates that the mean differences from no symptoms are statistically significant in Bonferroni multiple comparisons at $p$ value $<.05$.

** indicates that the mean differences from no symptoms are statistically signigicant in Bonferroni multiple comparisons at $p$ value $<.01$.

*** indicates that the mean differences from no symptoms are statistically signigicant in Bonferroni multiple comparisons at $p$ value $<.001$.

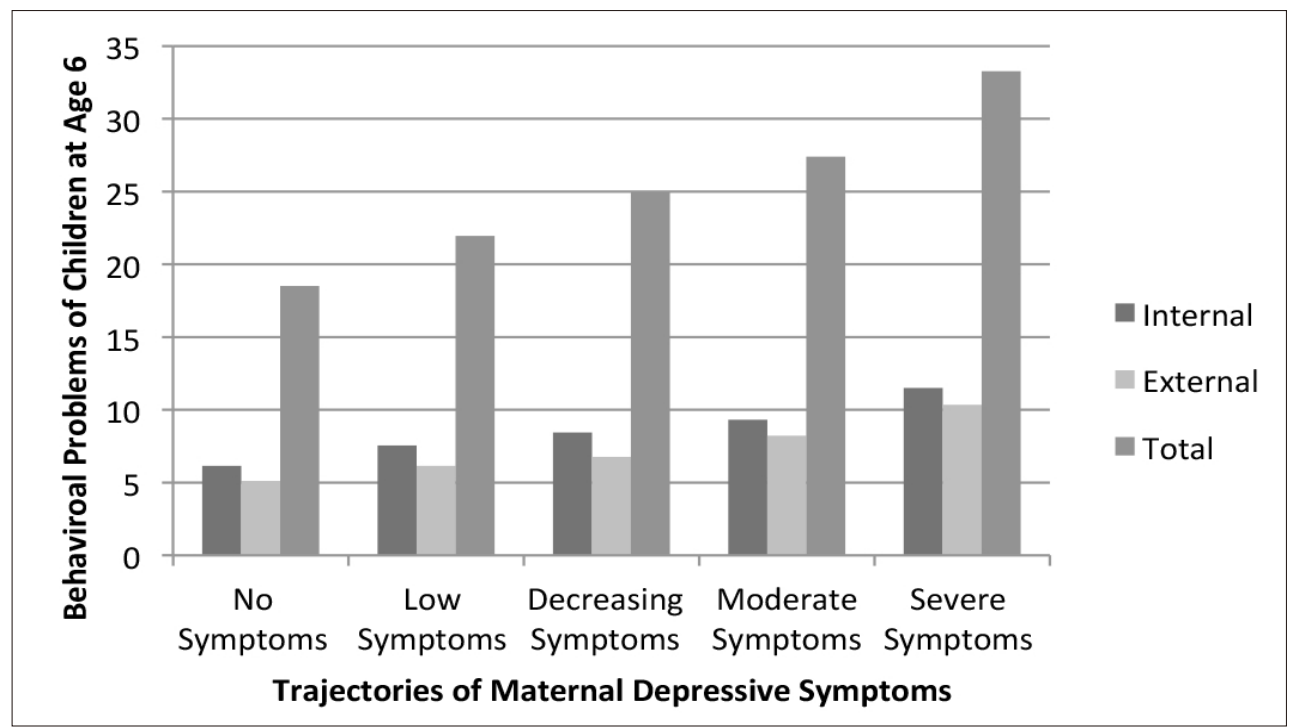

Figure 2. Behavioral problems of the first child at age 6 years according to trajectories of maternal depressive symptoms. 
여, 첫 자녀의 6세 때 문제행동 수준이 유의하게 높음을 알 수 있었다. 단, 증상완화 집단과 낮은 증상 집단 어머니들의 첫 자 녀 문제행동 수준은 증상 없음 집단 어머니들의 첫 자녀 문제 행동수준과 통계적으로 유의한 차이가 없었다.

\section{Discussion}

본 연구는 한국아동패널 자료를 활용하여 965 명의 어머니들 의 첫 출산 후 6 년 동안의 우울 발달궤적을 분석하고, 어머니 들의 우울 발달궤적에 따라 첫 자녀의 문제행동에 차이가 있 는지를 살펴보고자 하였다. 잠재성장 계층모형을 통해 우울 증상의 유사성에 의거하여 어머니들을 유형화하였고, 공분산 분석을 통해 통제변인의 영향력을 제거하고, 어머니들의 우울 궤적에 따라 첫 자녀 6세 때의 문제행동 수준에 차이가 있는지 를 검증하였다. 본 연구에서 도출된 결과를 연구 문제별로 논 의하면 다음과 같다.

첫째, 우리나라 어머니들의 첫 출산 후 6년 동안의 우울증 상은 크게 다섯 종류의 발달궤적으로 나뉠 수 있었다. 약 $26 \%$ 의 어머니들은 6년 간 반복적으로 실시된 총 9번의 자기 보고 식 우울 검사에서 일관성 있게 우울 증상을 거의 느끼지 않는 다고 하였다. 따라서 이들을 증상 없음 집단으로 명명하였다. 약 $43 \%$ 의 어머니들은 증상 없음 집단보다는 약간 높게 우울 증상을 지각하였으나 경도 우울의 기준이 되는 14 점에는 못 미치는 11 점 전후의 점수를 일관되게 유지하였다. 따라서 이 집단을 낮은 증상 집단으로 명명하였다.

약 7\%의 어머니들은 출산직후에서 출산 36개월 무렵까지 경도 우울에 해당하는 증상을 보고하였으나 점차로 증상이 완 화되었다. 이 집단을 증상 완화 집단으로 명명하였다. 약 $19 \%$ 의 어머니들은 출산 직후에는 14 점에 약간 못 미쳤으나 증상 이 점차로 심각해져서 6 년간 대부분의 시기에 경도에 해당하 는 우울 증상을 보였다. 이 어머니들을 경도 우울증상 집단으 로 명명하였다. 마지막으로 약 $6 \%$ 의 어머니들은 출산 직후에 는 경도 우울, 4 개월 이후부터는 중도 우울에 해당하는 증상 을 보고하였다. 이 어머니들의 우울 증상은 출산 후 48 개월 무 렵에는 무려 20점이 넘어가는 심각한 수준이었다. 이 어머니 들을 중도 우울증상 집단으로 명명하였는데, 주요 우울장애 (major depressive disorder)에 해당할 가능성이 상당히 높으며, 전문적인 치료와 상담이 필요할 것으로 보인다.

우리나라의 첫 출산한 어머니들의 우울 발달궤적을 분석한 결과 약 $25 \%$ 가 경도 또는 중도 수준의 상당한 우울증상을 만
성적으로 겪고 있음을 알 수 있었다. 증상 완화 집단 어머니들 의 우울 증상도 출산 후 36 개월까지는 경도 수준 이상임을 고 려하면, 첫 자녀 출생 후 만 3 세 까지 경도 이상의 우울 증상을 가진 우리나라의 어머니들은 약 $30 \%$ 에 달한다. 이러한 수치 는 같은 한국아동패널 자료를 활용하여, 출산 횟수를 고려하 지 않고 어머니들의 우울 발달궤적을 분석한 Y. H. Kim (2017) 의 연구와도 큰 차이가 있다. Y. H. Kim (2017)은 출산 후 4년 간의 어머니들의 우울 발달궤적을 분석하였는데, 출산 후 3 년 간 경도 우울 이상의 증상을 보고한 어머니들은 약 $15 \%$ 로 첫 출산한 어머니들을 대상으로 한 본 연구의 $30 \%$ 보다 훨씬 낮 았다. 이러한 결과는 첫 출산한 어머니들이 우울에 더 취약할 수 있음을 보여주는 것으로, 추후 어머니들의 우울과 관련된 연구나 중재를 실시함에 있어 출산 횟수를 반드시 고려해야 함을 의미한다.

한편, 모든 우울궤적에서 출산 후 한 달째에 우울증상이 일 시적으로 감소하는 현상이 나타났다. 이는 우리나라의 독특한 산후조리 문화에 기인하는 것으로 보인다. 출산 직후 약 3주 정도 친지나 전문 산후조리인의 도움을 받는 것이 어머니들의 우울을 일시적으로 감소하는데 기여한 것으로 보인다. 그러나 이러한 모든 우울 궤적에서 출산 후 4 개월부터 다시 우울 증상 이 큰 폭으로 상승한 것으로 보아, 산후 조리가 우울증상을 장 기적으로 개선하거나 우울 발달궤적을 변화시키는 효과가 있 는가는 확언하기 어렵다. 산후 조리 만족도가 산후 우울 감소 에 영향을 주었다는 연구결과(Youn \& Jeong, 2013)도 존재하 므로, 산후 조리와 어머니 우울간의 관계에 대한 보다 체계적 인 조사가 필요하다.

둘째, 첫 자녀의 만 6세 때 문제행동을 어머니들의 우울 궤 적을 독립변인으로 차이검증을 하였을 때, 증상 없음 집단의 첫 자녀에 비하여 경도 우울증상 집단과 중도 우울증상 집단 첫 자녀의 문제행동 수준이 유의하게 높았다. 이러한 결과는 아동의 성별, 부모의 교육수준, 가정 소득, 자녀의 문제행동을 평가할 당시(출산 후 72 개월) 어머니의 우울증상을 통제하고 도 통계적으로 유의하였다.

경도 우울증상 집단과 중도 우울증상 집단의 첫 자녀들은 생애 초기부터 만 6세에 이르기까지 상당한 수준의 만성적 인 어머니 우울을 경험한 아동들이다. 어머니 우울-아동 발달 과 관련하여 위험요소로 지목되고 있는 우울의 심각성과 만 성성 및 발달의 결정적 시기에 노출에 모두 해당하는 아동들 로, 예측한 바와 같이 내재적, 외현적, 문제행동 전체의 수준이 일반 어머니들의 첫 자녀에 비해 상당히 높았다. 이는 여러 문 화권에서 보고된 어머니 우울과 아동발달에 관한 연구결과들 
(Brennan et al., 2000; Campbell et al., 2007; Choi \& Kim, 2018; Goodman et al., 2011)과 같은 맥락이며, 만성적이고 심각한 어 머니의 우울은 아동의 발달, 특히 사회적으로 바람직한 행동 을 내재화하고 외현화 하는 데 부정적인 영향을 준다는 것이 다시 한 번 입증되었다.

다만, 증상 완화 집단 첫 자녀의 문제행동 수준은 증상 없 음 집단과 통계적으로 유의한 차이가 나타나지 않았다. 증상 완화 집단의 첫 자녀들은 경도 우울증상 집단의 아동들과 마 찬가지로 생애 초기(만 3세 이전)에 경도 이상의 어머니 우울 에 노출되었으나 만 3세 이후에는 어머니들의 우울 증상이 경 도 이하로 개선된 아동들이다. 즉, 경도 우울증상 집단 아동들 에 비하여 어머니 우울의 만성성이 비교적 낮은 아동들이다. 증상 완화 집단 첫 자녀들의 문제행동 수준은 증상 없음 집단 의 첫 자녀 문제행동 수준 보다는 기술적으로는 높았으나, 통 계적으로 유의한 차이는 없었다. 이는, 비록 아동이 생애 초기 에 어느 정도 심각한 수준의 어머니 우울에 노출되었을지라 도, 어머니 우울이 개선된다면 장기적으로는 아동의 사회적 문제해결 능력도 또래와 비슷한 수준으로 발달할 수 있음을 간접적으로 시사한다. 실제로 빈곤 가정을 대상으로 가족중심 중재를 실시하였더니, 어머니의 우울이 개선되고, 이를 매개 로 하여 유아기 자녀의 문제행동이 개선되었다는 외국의 연구 결과도 존재한다(Shaw, Connell, Dishion, Wilson, \& Gardner, 2009). 따라서 영유아기 자녀를 둔 어머니의 우울 증상이 발견 되면 이를 적극적으로 낮추려고 하는 노력이 필요하며, 이를 통해 아동의 사회적 능력도 개선할 수 있을 것이다.

한편, 본 연구에서는 첫 출산 직후에 측정된 우울 증상을 시 작으로 우울 발달궤적을 분석하였으나 임신 기간 중에 우울을 경험하는 임산부의 수도 상당한 것으로 알려져 있다(American Psychiatric Association, 2013). 실제로 본 연구에서도 출산 직후 에 병원에서 측정된 우울 검사가 “출산 전 한 달 동안 다음의 느낌을 얼마나 자주 느끼셨습니까?”를 묻고 있으므로 상당수 의 산모 특히, 중도 우울증상 집단의 산모는 임신 중에도 상당 한 우울감에 시달렸을 가능성이 크다. 산모가 우울하면 산모 의 신체는 신경생리학적으로 우울에 반응하며, 이는 태아에 게 직접적으로 전달되어 태중 발달에도 영향을 준다(Gentile, 2017). 태아기부터 어머니의 우울에 노출된 아동은 생물학적 인 발달적 취약성을 가지고 태어났을 수 있다. 또한 우울은 유 전적 소인도 강하기 때문에 우울한 어머니의 자녀는 우울에 취약한 유전적 성향을 물려받았을 가능성이 있고, 이는 아동 의 내재화된 문제행동 수준에 영향을 줄 수 있다(Betts et al., 2015). 따라서 본 연구의 종속 변인인 아동의 문제행동 수준에
는 우울로 인해 손상된 모-자녀 상호작용 뿐 아니라 이러한 생 물학적 유전적 요인이 복합적으로 영향을 주었을 것으로 추정 된다. 추후 보다 정교한 연구 설계를 통하여, 어머니 우울과 관 련된 1차적 요인(생물학적, 유전적 요인)과 2차적 요인(손상된 상호작용)이 아동의 발달에 주는 영향력을 구분하여 측정할 수 있다면, 중재의 범위와 효과를 설계하는데 크게 도움이 될 것으로 보인다.

종합하면, 본 연구는 어머니들의 우울증상은 그 증상의 유 사성에 따라 몇 개의 발달궤적으로 분류될 수 있으며, 심각한 수준의 어머니 우울에 만성적으로 노출된 아동은 발달상 문제 를 겪을 수 있음을 경고한 기존의 선행연구들과 유사한 결과 를 도출하였다. 우울이 어머니-자녀 상호작용을 손상시키고, 자녀의 두뇌구조 발달에도 부정적 영향을 주는 심각한 정신 건강 문제임을 고려할 때(Ashman et al., 2002; Campbell et al., 1995; Lebel, 2016), 첫 출산을 경험한 우리나라의 어머니들의 약 4 분의 1 이 상당한 수준의 만성적 우울에 고통 받고 있다는 것은 매우 심각한 문제이다. 이는 다시 말하면, 상당수의 아동 들이 생애 초기에 우울로 손상된 어머니-자녀 상호작용을 경 험하고 있다는 것이다. 다만, 비록 생애 초기에 어머니의 우울 에 노출되었다고 할지라도, 어머니의 우울이 개선되면 또래수 준의 행동 발달을 이룰 수 있음도 확인되었다. 따라서 첫 출산 후 경도 및 중등도 이상의 우울 증상을 보이는 어머니들을 선 별하고, 이들의 증상을 최대한 빨리 개선하는 것이 반드시 필 요하다고 하겠다. 이와 더불어 장시간 어머니의 우울증상에 노출된 아동들의 발달적 상태를 총체적으로 면밀히 분석하여, 문제행동을 대체할만한 바람직한 사회적 기술을 교육하는 것 도 수반되어야 한다.

본 연구는 첫 출산 후 어머니의 우울증상 궤적을 탐색한 우 리나라 첫 번째 시도로서, 향후 어머니의 우울증상 및 아동발 달과 관련된 후속 연구 및 중재프로그램 개발에 중요한 기초 자료를 제공하였다는 점에 그 의의가 있다고 하겠다. 본 연구 의 제한점 및 후속연구를 위한 제언은 다음과 같다. 첫째, 종단 연구의 특성상 자료의 마모율이 결과에 영향을 주었을 수 있 다. 어머니의 우울 발달궤적은 965 명의 어머니를 대상으로 분 석을 실시하였으나, 우울 발달궤적에 따른 아동의 문제행동 수준 차이는 6년간의 사례 수 마모로 인하여 633명을 대상으 로 분석이 이루어졌다. 둘째, 본 연구의 결과를 해석함에 있어 특히 주의해야 할 점은 경도 혹은 중도 우울증상 집단의 어머 니들이 우울증 진단을 정식으로 받은 것은 아니며, 자기보고 식 우울 검사도구의 절삭점에 의해 분류된 것이라는 점이다. 추후 정식으로 주요 우울증 진단을 받은 어머니들을 대상으로 
연구가 이루어질 필요가 있다. 마지막으로, 본 연구의 주요 변 인인 어머니의 우울과 아동의 문제행동 수준은 모두 어머니 의 보고에 의존하여 자료가 수집되었다. 아동의 문제행동 수 준 평가도 어머니에 의해 이루어졌는데, 비록 본 연구가 문제 행동 평정 당시 어머니들의 우울 증상을 통제하기는 하였으나 여전히 결과의 외적 타당도에 문제가 제기될 수 있다. 제 3자 가 측정한 아동의 사회적 능력을 종속변인으로 활용하는 추후 연구가 진행되어야 할 것이다.

\section{Notes}

This article was presented at the 2018 Annual Fall Conference of the Korean Association of Child Studies.

\section{Conflict of Interest}

No potential conflict of interest relevant to this article was reported.

\section{References}

\section{In English}

American Psychiatric Association. (2013). Diagnostic and statistical manual of mental disorders (DSM-5 ${ }^{\circ}$. Washington, DC: American Psychiatric Pub.

Ashman, S. B., Dawson, G., Panagiotides, H., Yamada, E., \& Wilkinson, C. W. (2002). Stress hormone levels of children of depressed mothers. Development and Psychopathology, 14(2), 333-349. doi:10.1017/S0954579402002080

Betts, K. S., Williams, G. M., Najman, J. M., \& Alati, R. (2015). The relationship between maternal depressive, anxious, and stress symptoms during pregnancy and adult offspring behavioral and emotional problems. Depression and Anxiety, 32(2), 82-90. doi:10.1002/da.22272

Brennan, P. A., Hammen, C., Andersen, M. J., Bor, W., Najman, J. M., \& Williams, G. M. (2000). Chronicity, severity, and timing of maternal depressive symptoms: Relationships with child outcomes at age 5. Developmental Psychology, 36(6), 759-766. doi:10.1037/0012-1649.36.6.759

Campbell, S. B., Cohn, J. F., \& Meyers, T. (1995). Depression in first-time mothers: Mother-infant interaction and depression chronicity. Developmental Psychology, 31(3), 349357. doi:10.1037/0012-1649.31.3.349

Campbell, S. B., Matestic, P., von Stauffenberg, C., Mohan, R., \& Kirchner, T. (2007). Trajectories of maternal depressive symptoms, maternal sensitivity, and children's functioning at school entry. Developmental Psychology, 43(5), 12021215. doi:10.1037/0012-1649.43.5.1202

Esposito, G., Manian, N., Truzzi, A., \& Bornstein, M. H. (2017). Response to infant cry in clinically depressed and non-depressed mothers. PLoS ONE, 12(1), e0169066. doi:10.1371/journal.pone.0169066

Fergusson, D. M., Lynskey, M. T., \& Horwood, L. J. (1993). The effect of maternal depression on maternal ratings of child behavior. Journal of Abnormal Child Psychology, 21(3), $245-$ 269. doi:10.1007/BF00917534

Gentile, S. (2017). Untreated depression during pregnancy: Short- and long-term effects in offspring. A systematic review. Neuroscience, 34(2), 154-166. doi:10.1016/ j.neuroscience.2015.09.001

Goodman, S. H., Rouse, M. H., Connell, A. M., Broth, M. R., Hall, C. M., \& Heyward, D. (2011). Maternal depression and child psychopathology: A meta-analytic review. Clinical Child and Family Psychology Review, 14(1), 1-27. doi: 10.1007/s10567-010-0080-1

Hammen, C., \& Brennan, P. A. (2003). Severity, chronicity, and timing of maternal depression and risk for adolescent offspring diagnoses in a community sample. Archives of General Psychiatry, 60(3), 253-258. doi:10.1001/ archpsyc.60.3.253

Jung, T., \& Wickrama, K. A. S. (2008). An introduction to latent class growth analysis and growth mixture modeling. Social and Personality Psychology Compass, 2(1), 302-317. doi:10.1111/j.1751-9004.2007.00054.x

Kessler, R. C., Barker, P. R., Colpe, L. J., Epstein, J. F., Gfroerer, J. C., Hiripi, E., . . \& \& Zaslavsky, A. M. (2003). Screening for serious mental illness in the general population. Archives of General Psychiatry, 60(2), 184-189. doi:10.1001/ archpsyc.60.2.184

Kim, Y. H. (2017). Trajectories of maternal depressive symptoms and behavioral problems of children at four years of age: Evidence from the panel study of Korean children. Child Indicators Research, 10(4), 1061-1078. doi:10.1007/ s12187-016-9417-8

Lebel, C., Walton, M., Letourneau, N., Giesbrecht, G. F., Kaplan, B. J., \& Dewey, D. (2016). Prepartum and postpartum maternal depressive symptoms are related to children's brain structure in preschool. Biological Psychiatry, 80(11), 859868. doi:10.1016/j.biopsych.2015.12.004

Mplus (Version 8.0). [Computer software]. Los Angeles, CA: Muthén \& Muthén. 
Muthén, B., \& Muthén, L. K. (2000). Integrating person-centered and variable--centered analyses: Growth mixture modeling with latent trajectory classes. Alcoholism: Clinical and Experimental Research, 24(6), 882-891. doi: 10.1111/ j.1530-0277.2000.tb02070.x

Shaw, D. S., Connell, A., Dishion, T. J., Wilson, M. N., \& Gardner, F. (2009). Improvements in maternal depression as a mediator of intervention effects on early childhood problem behavior. Development and Psychopathology, 21(2), 417-439. doi:10.1017/S0954579409000236

\section{In Korean}

Choi, E. J., \& Kim, C. K. (2018). Mothers' depression, happiness, family function, and children's behavioral problems: Structural relationships in different parental drinking contexts. Journal of Korean Council for Children \& Rights, 22(2), 215-237. doi:10.21459/kccr.2018.22.2.215

Hoe, M. (2014). Exploring latent trajectory classes of change in depression measured using CES-D. Korean Journal of Social Welfare, 66(1), 307-331.

Joh, E., \& Chang, H. (2018). The impact of maternal depressive symptom chronicity on child problem behaviors: The mediating role of maternal parenting behavior. The Korean Journal of Developmental Psychology, 31(3), 51-75.

Kim, A., \& Kim, H. J. (2018). Trajectories and determinants of life-satisfaction among South Korean children. Journal of Korean Council for Children or Rights, 22(1), 45-63. doi:10.21459/kccr.2018.22.1.45

Kim, C.-K., \& Cho, M.-K. (2017). The longitudinal relationship between mother's depression, parenting behavior and early child's behavior problem using latent growth model: A mediating effect of achievement values. Korea Journal of Child Care and Education, 106, 33-56.

Kim, S.-H. (2016). The longitudinal effect of young children's negative emotionality and maternal depression on internalizing behavior problems: Multivariate latent growth model. Early Childhood Education Research \& Review, 20(5), 421-446.

Kim, Y. A., Lee, J., Moon, S.-J., Kim, Y.-J., \& Oh, K. J. (2009). Standardization study for the Korean version of the Child Behavior Checklist for ages 1.5-5. The Korean Journal of Clinical Psychology, 28(1), 117-136.

Lee, J. Y., Lee, K. S., Chung, Y. K., \& Shin, Y. J. (2011). An analysis of interactions between mothers with postpartum depression tendencies and their infants. Korean Journal of Child Studies, 32(3), 203-220.

Lim, H., \& Choi, S. (2016). Developmental trajectories and predictors of adolescent depression: A short-term study. Korean Journal of Psychology: General, 35(3), 455-480. doi:10.22257/kjp.2016.09.35.3.455

Youn, J. H., \& Jeong, I. S. (2013). Predictors of postpartum depression: Prospective cohort study. Journal of Korean Academy of Nursing, 43(2), 225-235. doi:10.4040/ jkan.2013.43.2.225

Yoo, S. O. (2013). A clustering study of young children's challenging behaviors and occurrence rate through age 2 to 5. Korean Journal of Child Studies, 34(6), 57-75. doi:10.5723/KJCS.2013.34.6.57

\section{ORCID}

Yeon Ha Kim https://orcid.org/0000-0001-5547-2900

Received October 30, 2018

Revision received November 24, 2018

Accepted December 19, 2018 